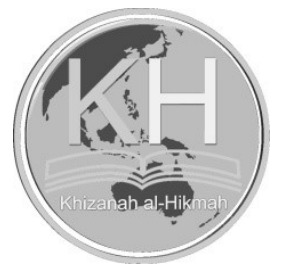

\title{
PERPUSTAKAAN DIGITAL DAN KELOMPOK PENGGUNA POTENSIAL
}

\author{
Dian Kristyanto*
}

*Universitas Wijaya Kusuma Surabaya

Email: diankristyanto@uwks.ac.id

(Submitted: 02-05-2019, Revised: 13-09-2019, Accepted: 01-12-2019)

DOI: $10.24252 /$ kah.v7i2a4

\begin{abstract}
ABSTRAK: Tipe pengguna potensial adalah kategori masyarakat yang tidak memiliki kesempatan ke perpustakaan karena keterbatasan fisik, waktu, hingga akses. Tujuan penelitian ini adalah memberikan sebuah perspektif tentang peranan lain dari perpustakaan digital sebagai media distribusi informasi yang dapat digunakan untuk menarik kelompok pengguna potensial. Implikasi yang dapat diperoleh yaitu optimalisasi peran perpustakaan digital dalam pemerataan sebaran informasi yang seimbang antara pengguna yang sering ke perpustakaan dan kelompok pengguna tertentu. Penelitian ini merupakan penelitian pustaka. Kajian ini menyimpulkan bahwa kelompok pengguna potensial memiliki hak yang sama terhadap informasi yang tersedia di perpustakaan, oleh karena itu distribusi informasi harus dilakukan secara efektif dan efisien melalui implementasi pengembangan perpustakaan digital sesuai dengan fungsi dan perannya sehingga pemerataan informasi dapat dilakukan secara maksimal karena kebutuhan masyarakat adalah prioritas perpustakaan.
\end{abstract}

Kata kunci: Perpustakaan Digital; distribusi informasi; pengguna potensial

\section{DIGITAL LIBRARY AND POTENSIAL USER GROUP}

ABSTRACT: Type of potential users is the category of people who do not have the opportunity to visit the library because of limitations, time, to access. The research objective is to provide a perspective on digital libraries as a medium of distribution of information that can be used to attract groups of potential users. The implication of the study is to optimize the role of digital libraries in the equitable distribution of information between users who frequently visit the library and certain user groups. The literature study was used as a method of gathering data. The study concluded that groups of users who have the potential to have the same rights to information available in libraries, therefore the distribution of information must be done effectively and efficiently through the construction of digital libraries in accordance with their functions and roles to make information equally and can be carried out appropriately as needed because the community needs are the priority.

Keywords: Digital Library; information distribution; potential users

\section{PENDAHULUAN}

Perpustakaan merupakan lembaga penyedia jasa informasi yang dibangun untuk mengelola dan mendistribusikan pengetahuan yang dikemas dalam bentuk informasi kepada masyarakat. Tujuan yang diharapkan dari proses tersebut ialah agar terbentuk peradaban bangsa yang maju dan cerdas, sehingga tercipta budaya masyarakat yang lebih peduli terhadap pengetahuan, dan pada akhirnya akan muncul pola masyarakat yang dengan sengaja hadir dan memanfaatkan perpustakaan sebagai upaya meningkatkan perbendaharaan berpikir yang bersumber dari informasi yang valid dan berkualitas. 
Perpustakaan memiliki peranan besar dalam proses organisasi informasi yang diolah dari berbagai sumber literatur hasil karya cipta manusia yang dilayankan kembali pada masyarakat penggunanya. Oleh karena itu, berbagai upaya telah dilakukan pustakawan dalam rangka melakukan pengembangan sebagai rencana strategis agar tujuan perpustakaan untuk memberikan pelayanan terbaik bagi masyarakat dapat tercapai sesuai rencana.

Akan tetapi berbicara tentang masyarakat pengguna perpustakaan, maka tidak semua pemustaka yang menjadi sasaran perpustakaan memiliki kesempatan yang sama untuk memanfaatkan perpustakaan. Banyak faktor yang mempengaruhi kesempatan mereka untuk berkunjung ke perpustakaan seperti keterbatasan waktu, akses lokasi yang sulit, hingga pada kondisi individu yang tidak memungkinkan untuk berkunjung ke perpustakaan, sementara mereka bisa saja menginginkan informasi yang sama dengan pengguna lainnya melalui perpustakaan.

Pada setiap perpustakaan, tentunya memiliki masyarakat pengguna yang hampir tidak pernah datang ke perpustakaan karena sesuatu hal, pemustaka memiliki karakteristik dan sikap yang heterogen antara satu dengan lainnya, atau memiliki problematika hidup yang berbeda hingga latar belakang yang berbeda. Salah satu jenis perpustakaan yang memiliki masyarakat pengguna yang heterogen adalah perpustakaan umum dan daerah. Pada perpustakaan umum dan daerah tentunya sasaran yang dituju adalah masyarakat yang ada di daerah sesuai lokasi perpustakaan diselenggarakan. Masyarakat pengguna perpustakaan umum dan daerah terdiri dari berbagai macam latar belakang baik dari segi pendidikan, ekonomi, sosial, budaya dan kondisi geografis. Permasalahan terhadap masyarakat pengguna pada perpustakaan umum dan daerah merupakan salah satu contoh kecil yang menggambarkan bahwa tugas perpustakaan dalam memberikan pelayanan dan distribusi informasi cukup berat, sehingga membutuhkan strategi yang tepat supaya layanan perpustakaan terkait penyebaran informasi dapat tersampaikan dengan baik kepada masyarakat pengguna.

Menurut Yusup (2009, p. 330) masyarakat pengguna perpustakaan yang belum sempat datang ke perpustakaan disebut sebagai potential users, di mana mereka tergolong orang-orang yang membutuhkan pelayanan dari perpustakaan namun dengan harapan pengelola perpustakaan mendatangi mereka di rumah-rumah kediamannya untuk menyajikan informasi yang mereka dibutuhkan. Masyarakat yang tergolong sebagai potential users sangat beragam, salah satu contoh adalah kelompok masyarakat yang memiliki keterbatasan fisik dan psikologis di mana kelompok ini tidak memungkinkan untuk datang ke perpustakaan karena faktor keterbatasan yang dialaminya.

Bicara tentang masyarakat pengguna perpustakaan yang memiliki keterbatasan fisik dan psikologis memang sangat sensitif mengingat tidak banyak perpustakaan yang siap memberikan pelayanan lebih kepada kelompok masyarakat disabilitas. Padahal mereka merupakan potential users bagi perpustakaan yang wajib untuk diberikan fasilitas dan layanan yang sama dengan pengguna aktif perpustakaan lainnya.

Kelompok masyarakat lain yang tergolong sebagai potential users bagi perpustakaan adalah kelompok masyarakat pekerja, di mana mereka menghabiskan waktu untuk bekerja mencari nafkah sehingga tidak ada kesempatan dan waktu luang untuk berkunjung ke perpustakaan. Badan Pusat Statistik (BPS) mencatat pada Februari 2018 jumlah penduduk Indonesia yang bekerja sebanyak 127,07 juta orang, dan bertambah 2,53 juta orang dibanding Februari 2017 (Badan Pusat Statistik, 2018).

Memberikan pelayanan bagi kelompok potential users bukan perkara yang mudah diimplementasikan secara cepat oleh perpustakaan. Namun demikian, pengelola perpustakaan tetap wajib memberikan perhatian khusus kepada mereka karena hal tersebut menjadi kewajiban perpustakaan, terutama dalam mendistribusikan informasi yang dikelolanya pada 
masyarakat. Oleh sebab itu, diperlukan strategi inovasi pengembangan yang tepat supaya pelayanan informasi bagi kelompok potential users dapat terwujud. Pertumbuhan teknologi yang sangat tinggi serta didukung dengan pengembangan-pengembangan yang inovatif pada sektor teknologi dapat menjadi salah satu solusi bagi institusi/lembaga yang bergerak dalam bidang pelayanan (jasa) dalam melayani potential users yang berbasis teknologi informasi.

Perpustakaan digital menjadi bagian dari inovasi pengembangan perpustakaan yang dibangun untuk menarik masyarakat pengguna dalam jumlah besar. Selain itu, keberadaan perpustakaan digital memungkinkan untuk menjangkau kelompok pengguna yang masuk dalam kelompok pengguna potensial. Pengembangan perpustakaan digital merupakan salah satu strategi yang dapat dioptimalkan sebagai media distribusi informasi secara merata. Walaupun memang perpustakaan digital bukanlah kunci utama dalam menarik masyarakat untuk memanfaatkan perpustakaan, namun keberadaannya cukup berpengaruh sebagai salah satu media komunikasi dan distribusi informasi yang penting bagi perpustakaan. Oleh itu penelitian ini bertujuan untuk mengkaji tentang pengembangan perpustakaan digital yang dapat menjangkau kelompok-kelompok pengguna potensial yang jarang tersentuh oleh perpustakaan.

\section{KAJIAN TERDAHULU}

Kajian mengenai perpustakaan digital telah banyak bermunculan karena bidang kajian perpustakaan digital menjadi kajian yang menarik untuk ditelaah lebih lanjut. Seiring perkembangan teknologi informasi dan dorongan untuk meningkatkan pelayanan, maka salah satu sinergitas antara perpustakaan dan teknologi adalah melahirkan pengembangan perpustakaan digital.

Penelitian tentang perpustakaan digital pernah dilakukan oleh Singh, Sharma, \& Singh, (2015), yang membahas tentang konsep penerimaan dan konstruksi sosial terhadap munculnya perpustakaan digital. Penelitian ini menggunakan metodologi survei yang melibatkan pustakawan, dosen, mahasiswa pascasarjana serta mahasiswa sarjana di beberapa universitas yang ada di India sebagai responden. Hasil temuan penelitian ini menunjukkan bahwa perpustakaan digital dapat diterima dan lebih berguna untuk kelompok pengguna.

Penelitian lain tentang perpustakaan digital juga muncul dari Rahimi et al., (2018) yang meneliti tentang evaluasi perpustakaan digital. Berbeda dengan penelitian sebelumnya yang menggunakan pendekatan survei sebagai metodologinya, penelitian ini menggunakan pendekatan analisis studi pustaka dengan melakukan analisis terhadap pencarian beberapa artikel ilmiah terpublikasi terkait dengan subjek perpustakaan digital. Analisis dilakukan pada 64 artikel terbitan tahun 2004-2017 yang ditemukan melalui Springer, Science Direct, ProQuest, Emerald, Wiley, LISTA, Web of Science (WOS), Scopus dan lainnya. Hasil analisis yang disampaikan pada penelitian ini menjelaskan jika evaluasi perpustakaan digital sebagian besar masih berfokus pada aspek kualitas pelayanan dan pendekatan DigiQual menjadi model evaluasi yang paling sering digunakan.

Penelitian yang dilakukan oleh peneliti di atas pada tahun 2018 tersebut memberi sebuah isyarat bahwa kajian mengenai evaluasi perpustakaan sangat diminati oleh para peneliti. Kajian tentang evaluasi perpustakaan digital seolah-olah mengisyaratkan jika memang pengembangan perpustakaan digital perlu pengkajian lebih lanjut mengenai fungsi, peran dan sasarannya sehingga tidak hanya sekedar melakukan pengembangan. Penelitian evaluasi perpustakaan digital juga dilakukan oleh Firozjah, Dizaji, \& Hafezi (2019), penelitian ini mengkaji tentang evaluasi kegunaan (usability evaluation) dari perpustakaan digital yang dilakukan di beberapa universitas negeri di Teheren, Iran. Penelitian ini menggunakan sampel sebesar 378 responden yang dibagi menjadi 130 orang diambil dari Universitas Teheren, 125 orang dari Universitas Amirkabir dan 123 orang dari Universitas Sharif. Hasil penelitian ini menunjukkan bahwa 
perpustakaan digital dinyatakan signifikan dengan kriteria usabilitas meliputi measures of search, navigation, forms layout, contrast and scan ability, optimization, help, usage of windows and speed and errors. Hal tersebut menunjukkan bahwa perpustakaan digital masih sering dikunjungi oleh berbagai kelompok pengguna sesuai dengan tujuan yang diharapkan oleh pihak manajemen perpustakaan.

Beberapa penelitian yang disampaikan di atas merupakan kajian-kajian tentang perpustakaan digital yang didominasi sistem evaluasi terhadap perpustakaan digital. Hal tersebut berbeda dengan penelitian ini, sebab yang dikaji dalam penelitian ini yaitu pengembangan perpustakaan digital sebagai upaya dalam melayani potential users. Metode yang digunakan beberapa penelitian tersebut juga berbeda dengan penelitian ini, di mana penelitian yang telah disebutkan sebelumnya menggunakan metode survei, pemetaan penelitian, dan kuesioner. Adapun metode yang digunakan penelitian ini yaitu studi pustaka yang akan dibahas lebih lanjut pada pembahasan selanjutnya.

\section{METODOLOGI PENELITIAN}

Pendekatan yang digunakan pada kajian ini adalah pendekatan penelitian kepustakaan atau dikenal dengan istilah riset pustaka. Zed (2008, p. 1) menjelaskan sebagai salah satu metode yang memanfaatkan sumber perpustakaan untuk memperoleh data penelitian. Selain itu riset pustaka membatasi kegiatannya hanya pada bahan rujukan yang ada pada perpustakaan saja tanpa memerlukan riset lapangan. Teknik pengumpulan data melalui telaah berbagai sumber referensi, menurut Nazir (2013, p. 93) studi pustaka menggunakan metode pengumpulan data melalui penelaahan terhadap buku, literatur, catatan-catatan dan laporan-laporan yang terkait dengan permasalahan yang sedang dipecahkan. Menurut Hermawan (2019, p. 17) studi pustaka apabila ditinjau dari sumbernya dibedakan menjadi dua yaitu kepustakaan konseptual dan kepustakaan penelitian. Kepustakaan konseptual meliputi konsep-konsep atau teori-teori yang ditulis oleh para ahli dan dimuat dalam bentuk buku, sedangkan kepustakaan penelitian meliputi laporan penelitian yang telah dipublikasikan dalam jurnal maupun majalah ilmiah. Merujuk pada tinjauan mengenai studi pustaka, maka analisa kajian bersumber pada jurnal ilmiah yang fokus pada tema perpustakaan digital dan buku sebagai sumber sekunder yang digunakan sebagai data pendukung terutama untuk penekanan teoritis. Sementara itu, analisis data menggunakan pendekatan analisis isi deskriptif (descriptive content analysis). Menurut Eriyanto (2011: 3) analisis isi deskriptif yaitu analisis sebuah isi (konten) yang dimaksudkan untuk menggambarkan secara detail suatu pesan atau teks tertentu. Pesan yang dimaksud adalah pesan yang diperoleh dari hasil telaah tekstual terhadap sumber-sumber ilmiah.

\section{HASIL DAN PEMBAHASAN}

\section{Kebutuhan Pengguna Berdasarkan Tipe Pengguna Potensial}

Kebutuhan informasi merupakan kondisi di mana seseorang memerlukan tambahan pengetahuan yang digunakan untuk melengkapi pengetahuan yang sudah dimilikinya, sehingga mendorong mereka untuk melakukan pencarian terhadap informasi baru. Menurut Krikelas (1983) yang dikutip dalam Juhaidi \& Syawqi (2016, p. 23) kebutuhan informasi muncul ketika pengetahuan yang dimiliki oleh seseorang kurang dari yang dibutuhkan sehingga mendorong seseorang untuk mencari informasi baru yang digunakan untuk menambah pengetahuan yang sudah ada sebelumnya. Menurut Yusup (2009, p. 330) pengguna informasi dalam pandangan perpustakaan dibagi sekurangnya dua tipe. Pertama, potential users adalah kelompok pengguna atau masyarakat yang belum sempat dilayani oleh perpustakaan namun kelompok tersebut sebenarnya membutuhkan pelayanan dari perpustakaan dengan harapan pelayanan dapat sampai ke rumah kediamannya., kedua ada actual user yaitu mereka yang sudah datang ke perpustakaan atau sudah memanfaatkan jasa layanan perpustakaan disebut dengan pengguna aktual.

Kelompok pengguna potensial (potential users) menjadi pembahasan pokok karena memang kelompok pengguna informasi ini sering luput dari perhatian pengelola perpustakaan. Connaway (2015) menjelaskan bahwa potential users sebagai kelompok/individu masyarakat yang tidak pernah atau jarang menggunakan layanan perpustakaan. Kelompok pengguna ini 
hampir tidak pernah mengunjungi perpustakaan karena suatu hal yang membuat jarak antara mereka dengan perpustakaan tetap jauh. Akan tetapi, pada hakikatnya mereka menginginkan pelayanan perpustakaan karena kebutuhan mereka terhadap informasi sama dengan kelompok pengguna yang sering memanfaatkan perpustakaan.

Kelompok pengguna potensial perpustakaan memandang kebutuhan informasi sebagai sesuatu yang ingin mereka peroleh namun terkendala waktu, akses maupun keterbatasan lain yang membuat mereka merasa kesulitan untuk mendapatkan informasi. Memang bukan perkara mudah untuk menentukan kebutuhan pengguna karena membutuhkan sebuah riset analisis kebutuhan untuk mengetahui keinginan pengguna terhadap informasi di perpustakaan. Akan tetapi, asumsi dasar terhadap kebutuhan pengguna potensial perpustakaan adalah mereka tentunya menginginkan informasi yang sama dengan pengguna lain, serta beberapa informasi lain yang lebih spesifik dan khusus untuk mendukung tujuan dari mereka mendapatkan informasi tersebut.

Pengguna potensial dalam bidang perpustakaan adalah masyarakat yang tidak pernah datang ke perpustakaan karena sesuatu hal yang membuat mereka tidak memiliki kesempatan untuk ke perpustakaan. Kelompok pengguna potensial perpustakaan tidak dominan diisi oleh masyarakat yang memiliki keterbatasan secara fisik dan mental saja, namun cakupan kelompok ini semakin diperluas pada masyarakat yang tidak memiliki waktu, jarak yang tidak memungkinkan untuk ke perpustakaan hingga mereka yang berstatus baru lahir di tengah masyarakat. Pengguna potensial perpustakaan memiliki beragam karakteristik karena latar belakang mereka yang berbeda, hal ini menarik karena keberagaman karakter dari pengguna potensial perpustakaan memberikan tantangan bagi pustakawan untuk merancang rencana strategi yang tepat sasaran supaya mereka dapat menerima distribusi informasi dari perpustakaan sesuai dengan kebutuhan masing-masing dari pengguna potensial.

Kebutuhan informasi yang dimiliki oleh pengguna potensial perpustakaan dapat dilihat dari karakteristik pengguna yang tergolong kelompok pengguna potensial. Tipe pengguna potensial perpustakaan menentukan informasi apa yang diinginkan, sebagai contoh seorang remaja yang mengalami kelumpuhan membuat dia tidak dapat melakukan aktifitas selayaknya remaja normal yang bisa bermain dan berangkat ke sekolah. Remaja ini tentunya sangat ingin mendapatkan informasi yang belum tentu akan dia dapatkan melalui internet. Anak tersebut akan memiliki keinginan untuk mendapatkan pengetahuan yang sama dengan anak lain yang normal yaitu pengetahuan yang diperoleh melalui pendidikan. Hal ini tentunya harus diperhatikan betul oleh berbagai pihak terutama pustakawan untuk peka terhadap masyarakat yang tidak bisa secara langsung datang ke perpustakaan. Contoh di atas hanyalah sebagian kecil realitas yang terjadi di masyarakat di mana tidak semua orang mampu untuk datang ke perpustakaan dan menikmati informasi sebagaimana yang orang lain lakukan. Bagi pustakawan, maka hal tersebut menjadi tantangan sehingga tidak akan ada diskriminasi informasi pada masyarakat karena perpustakaan berperan untuk mendistribusikan informasi secara merata.

Tipe pengguna potensial sendiri dapat dibedakan beberapa macam, seperti mereka yang dinyatakan memiliki hambatan fisik dan mental serta tipe tersebut berkembang lebih luas dengan menempatkan orang-orang normal namun tidak memiliki kesempatan untuk ke perpustakaan sebagai golongan dari pengguna potensial. Adapun kelompok yang termasuk dalam pengguna potensial antara lain;

1. Mereka yang mengalami gangguan fisik atau lemah (infirm) sehingga tidak mampu menggunakan jasa layanan perpustakaan secara konvensional

2. Mereka yang mengalami gangguan atau lemah (infirm) sehingga tidak dapat melakukan perjalanan ke perpustakaan

3. Mereka yang secara mental sedang dirundung duka sehingga merasa malu untuk ke perpustakaan

4. Anak-anak yang masih dalam asuhan orang dewasa di rumah

5. Mereka yang secara prosedur dan aturan sedang tidak diperbolehkan untuk meminjam langsung ke perpustakaan, contohnya narapadina

6. Mereka yang mempunyai kesibukan luar biasa dalam pekerjaannya sehingga tidak ada kesempatan untuk ke perpustakaan 
7. Orang-orang yang hidup di daerah terpencil dan jauh dari pelayanan perpustakaan. (Ryder (1987) dalam Yusup (2009, p. 331).

Dengan melihat kelompok pengguna potensial seperti yang dijelaskan Ryder, maka pustakawan dapat melakukan hipotesis tentang kebutuhan informasi sesuai dengan tipe masing-masing pengguna potensial. Setiap kelompok tentunya memiliki tingkatan tantangan yang berbeda karena karakteristiknya juga berbeda antara satu dengan lainnya. Akan tetapi pemanfaatan teknologi di perpustakaan dapat dikembangkan, sehingga mampu menjalankan peran dan fungsinya untuk menjangkau beberapa pengguna potensial.

\section{Perpustakaan Digital Sebagai Layanan yang Ramah bagi Kelompok Pengguna Potensial}

Perkembangan perpustakaan di era teknologi informasi saat ini sangatlah berguna terlebih dalam hal pelayanan pada masyarakat. Perkembangan tersebut juga berjalan cukup cepat hingga telah banyak konsep pengembangan baru yang ditawarkan dalam hal kemudahan akses, peningkatan pelayanan hingga mempermudah sebaran informasi pada masyarakat. Pengembangan perpustakaan telah didorong dengan adanya pembangunan infrastruktur berbasis teknologi, hal ini dapat dilihat dari adanya pemanfaatan sistem otomasi perpustakaan, pemasangan WiFi untuk peningkatan infrastruktur akses informasi melalui internet, pengembangan layanan e-jurnal hingga pada pengembangan perpustakaan digital.

Dari beberapa pengembangan infrastruktur berbasis teknologi, pengembangan perpustakaan digital sangat gencar dilaksanakan baik pada level perguruan tinggi, perpustakaan daerah maupun perpustakaan sekolah. Pengembangan perpustakaan digital (digital library) jika diamati lebih jauh merupakan sebuah konsep pengembangan dari sistem otomasi perpustakaan. Pembangunan perpustakaan digital dilakukan untuk memberikan kemudahan bagi pemustaka memperoleh informasi yang dimiliki perpustakaan. Pengembangan perpustakaan digital diharapkan mempermudah akses bagi pemustaka untuk dapat menjangkau informasi secara online, berbeda dengan sebelumnya di mana pembangunan sistem otomasi perpustakaan masih cenderung dijalankan secara offline namun tidak dapat disangkal pula jika saat ini masih ada pengembangan perpustakaan digital yang dijalankan melalui format dua jaringan yaitu offline dan online.

Pengembangan perpustakaan digital memang sangat penting mengingat informasi saat ini sudah dapat diakses melalui jaringan internet, sementara perpustakaan yang menjadi pusat sumber informasi dan pengetahuan tentunya tidak dapat berdiam diri tergerus oleh perkembangan pemanfaatan internet yang pesat sehingga perpustakaan perlu bergerak dengan membuat inovasi pelayanan informasi yang berbasis pada jaringan internet. Perlu kita pahami jika masyarakat kita cenderung aktif dalam menggunakan internet, termasuk di antaranya kelompok masyarakat yang masuk dalam kategori pengguna potensial perpustakaan juga cenderung menggunakan internet daripada harus berkunjung ke perpustakaan.

Berbicara tentang pengguna potensial perpustakaan dan kaitannya dengan perpustakaan digital, maka ada hasil penelitian yang mendukung kenapa perlu adanya perpustakaan digital dewasa ini. Hasil penelitian yang dilakukan antara tahun 2011 hingga 2012 dari Shea-Budgell, Kostaras, Myhill, \& Hagen (2014) tentang kebutuhan informasi dan sumber informasi yang digunakan oleh penyandang kanker menghasilkan temuan jika sebanyak 236 responden $(57,4 \%)$ sumber informasi yang sering diakses oleh responden adalah internet, kemudian sumber informasi seperti buku berada pada posisi ke-enam sebagai sumber informasi yang banyak diakses responden penyandang kanker yaitu 66 responden $(16,1 \%)$. Sedangkan jumlah responden yang memilih perpustakaan sebagai sumber informasi sebanyak 18 responden $(4,4 \%)$ sehingga membuat perpustakaan berada pada posisi ke-12 sebagai sumber informasi yang sering diakses penyandang kanker. Adapun Penelitian lainnya terhadap penyandang kanker di klinik Tom Bake Cancer Centre (Calgary, Kanada) dan Holy Cross Centre (Calgary, Kanada) menunjukkan jika akses informasi melalui internet menjadi langkah utama bagi mereka yang sedang membutuhkan informasi yang terkait dengan kebutuhannya. Sedangkan buku dan perpustakaan seperti sebuah opsi kedua dan ketiga bagi mereka mengingat beberapa kendala yang mungkin mereka hadapi untuk bisa membeli buku atau membaca buku di perpustakaan. Kelompok-kelompok seperti inilah yang masuk dalam kategori pengguna potensial 
perpustakaan yang perlu difasilitasi dan dilayani. Oleh sebab itu pengembangan perpustakaan digital akan dirasa mampu memberikan solusi penting bagi kelompok tersebut.

Pengembangan perpustakaan digital yang telah dijalankan oleh beberapa perpustakaan, baik pada tingkat perguruan tinggi hingga perpustakaan sekolah sejauh ini memang masih sebatas pada menampilkan metadata koleksi pada Online Public Access Catalogue (OPAC)/katalog online perpustakaan sehingga memberi kemudahan bagi pemustaka untuk menemukan di mana posisi buku tersebut berada di rak. Masih cukup banyak perpustakaan yang memberikan nama pada OPAC-nya dengan menambahkan kata "digilib" pada URL situs OPAC masing-masing sehingga sudah dianggap telah melakukan pengembangan ke arah perpustakaan digital.

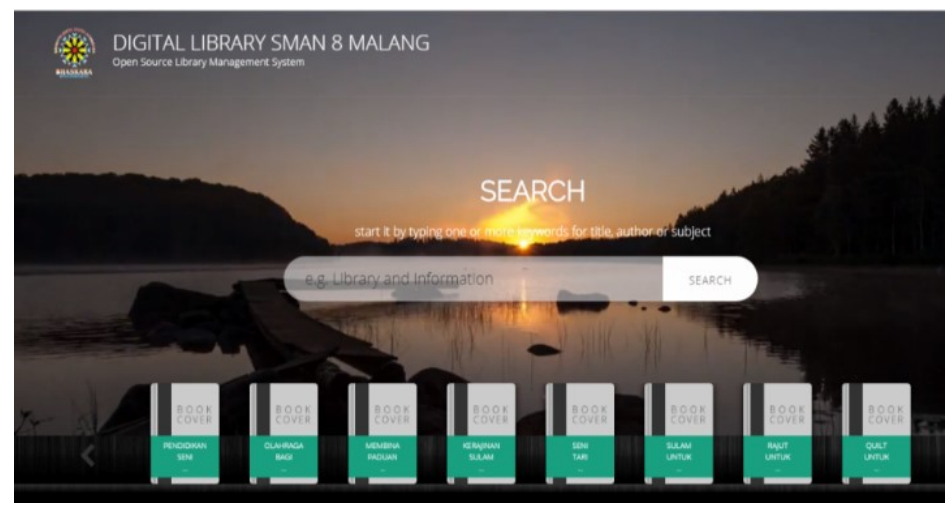

Gambar 1. Contoh perpustakaan digital berbasis SLiMS

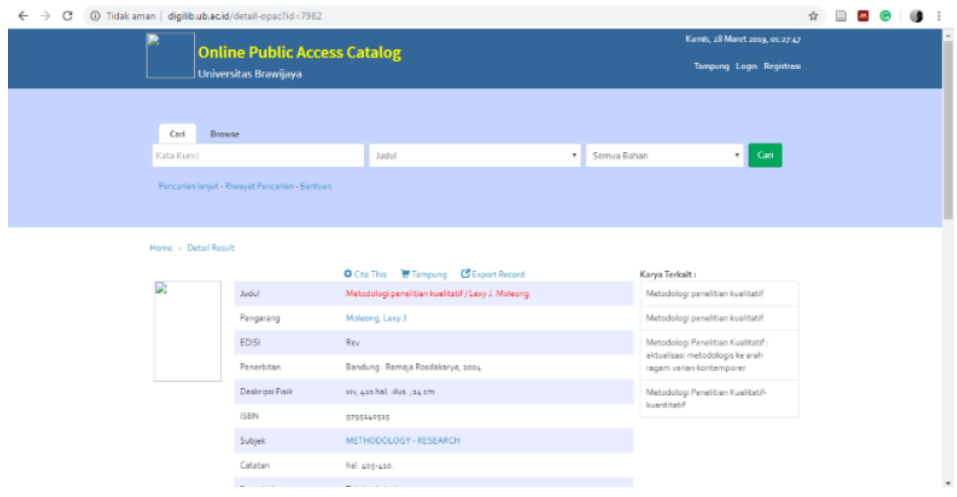

Gambar 2. Contoh perpustakaan digital berbasis Inlislite

Keduan contoh di atas menggunakan program berbeda, namun ada satu kesamaan antara kedua situs di atas, di mana keduanya menambahkan kata "digital" pada masing-masing alamat URL. Pada gambar 1 dijelaskan jika alamat URL adalah digilib-sman8mlg.web.id/ sedangkan untuk URL perpustakaan UB adalah digilib.ub.ac.id/detail-opac?id=7982. Hal ini tentunya memberikan sebuah gambaran jika pengembangan perpustakaan digital masih terbatas pada pemanfataan aplikasi perpustakaan untuk kegiatan otomasi dan sistem temu kembali informasi di perpustakaan. Pengembangan tersebut memang sudah cukup membantu namun hanya bagi pengguna aktual yaitu pengguna perpustakaan yang sudah pernah ke perpustakaan. Sedangkan bagi pengguna potensial perpustakaan pengembangan perpustakaan digital tidak sebatas pada media penelusuran online saja melainkan mereka butuh fasilitas di mana kebutuhan mereka terhadap informasi terpenuhi tanpa harus ke perpustakaan untuk meminjam buku yang sudah dipesan.

Desain pengembangan perpustakaan digital tentunya harus dibuat tidak hanya menarik namun juga membantu dan bisa digunakan oleh semua kelompok pengguna. Namun, sebelumnya pustakawan hendaknya memahami dengan baik konsep perpustakaan digital, tujuan yang ingin dicapai dengan pengembangan perpustakaan digital hingga kesiapan institusi 
dalam menyediakan sumber daya yang mendukung terciptanya perpustakaan digital. Adapun dalam membangun perpustakaan digital sangat perlu bagi pustakawan memahami karakteristik perpustakaan digital sehingga perencanaan terhadap kebijakan pengembangan perpustakaan digital tidak sia-sia. Karakteristik perpustakaan digital dijelaskan oleh Chowdury \& Chowdury (2003, p. 8) adalah sebagai berikut;

1. Perpustakan digital berisikan berbagai sumber informasi digital berupa teks, gambar, audio maupun video

2. Perpustakaan digital mengurangi kebutuhan terhadap penggunaan ruangan secara fisik

3. Pengguna perpustakaan digital bisa tersebar diseluruh dunia

4. Pengguna perpustakaan digital dapat membuat koleksi pribadi menggunakan fasilitas yang disediakan perpustakaan digital (personalisasi)

5. Menyediakan akses ke berbagai sumber informasi yang terletak pada server yang berbeda

6. Pengguna dapat menggunakan sumber informasi secara bersamaan pada waktu yang sama

7. Perpustakaan mengubah paradigma dalam penggunaan informasi dari awalnya print to digital menjadi ownership (konsep kepemilikan)

8. Perpustakaan digital memungkinkan untuk mengubah peran pustakawan menjadi online customer service

9. Perpustakaan digital harus dilengkap dengan fasilitas searching and information retrieval

10. Perpustakaan digital menyediakan informasi digital sesuai dengan kebutuhan masyarakat yang heterogen

11. Perpustakaan digital memutus hambatan ruang, waktu dan bahasa.

Karakteristik perpustakaan digital sangat perlu dipahami oleh pihak pustakawan maupun kepala perpustakaan supaya dalam pengembangannya sejalan dengan tujuan yang ingin dicapai. Pengembangan perpustakaan digital akan sangat bermanfaat dan dapat menjadi sebuah solusi dalam mendistribusikan informasi perpustakaan kepada seluruh elemen masyarakat khususnya kelompok pengguna potensial. Selain itu, perlu adanya evaluasi terkait pengembangan perpustakaan digital yang sudah berjalan, hal ini merujuk pada isi dari perpustakaan digital yang ada saat ini lebih pada katalog online, fungsinya masih terbatas pada sistem temu kembali informasi yang mana masyarakat masih perlu datang ke perpustakaan. Pengembangan perpustakaan digital saat ini masih perlu ditingkatkan terutama fasilitas yang lebih dapat diterima oleh masyarakat tertentu seperti kelompok pengguna potensial, mereka membutuhkan informasi yang dapat dibaca pada saat itu juga sehingga mereka tidak perlu lagi datang ke perpustakaan untuk melakukan transaksi peminjaman atau sekedar membaca di tempat.

Desain perpustakaan digital yang ramah (friendly) tentunya menjadi harapan bagi setiap kelompok, baik dari pustakawannya maupun penggunanya, akan banyak manfaat yang dihasilkan apabila desain pengembangan perpustakaan digital dirancang sesuai dengan tujuan perpustakaan. Desain pengembangan perpustakaan digital merupakan suatu rancangan dasar yang dapat dijadikan acuan/pegangan dalam pembangunan perpustakaan digital. Desain di sini bukan sekedar bicara tentang tampilan (interface) dari perpustakaan digital yang harus dikemas menarik, namun desain di sini adalah rancangan konseptual tentang persiapan apa saja yang diperlukan di dalam pengembangan perpustakaan digital sehingga pembangunannya dapat benar-benar berguna bagi seluruh kelompok pengguna. Mengingat pentingnya peran perpustakaan digital dalam menjangkau pengguna potensial perpustakaan, maka banyak hal yang perlu diperhatikan sehingga pengembangan perpustakaan tidak berjalan lambat serta mengalami kegagalan fungsi dan perannya. Oleh karena itu ada empat faktor yang perlu diperhatikan sebelum melakukan pengembangan perpustakaan digital (Singh et al., 2015) antara lain ;

\section{a. Perception of relevant social groups}

Dalam proses pengembangan perpustakaan, maka pengelola (pustakawan) perlu melihat, memahami dan menganalisis persepsi/tanggapan yang menjadi harapan masyarakat khususnya kelompok-kelompok sosial tertentu yang masuk dalam kategori potential users terhadap pengembangan yang akan dilakukan oleh perpustakaan. Faktor ini dapat menentukan arah pengembangan perpustakaan digital, apalagi jika pengembangan ini dikhususkan untuk menarik pengguna potensial yang merupakan kelompok masyarakat khusus bagi perpustakaan. Faktor 
ini dapat mendefinisikan kebutuhan serta syarat yang diajukan oleh kelompok pengguna tertentu berdasarkan pada pengalaman yang mereka dapatkan, kondisi kerja, hingga pengaruh sosial dan budaya dari kelompok pengguna tersebut.

\section{b. User Learning}

Pengembangan perpustakaan digital harus dapat meningkatkan peran perpustakaan dalam pelayanan berbasis digital supaya dapat mempercepat proses penerimaan bagi pengguna potensial perpustakaan. Faktor ini menekankan pada pengembangan fasilitas yang ada pada portal perpustakaan digital, penguatan proses pemasaran dan promosi perpustakaan digital, pelatihan (training) bagi pustakawan dan pengguna perpustakaan terhadap tata cara penggunaan fasilitas perpustakaan digital dan merancang tujuan dari pengembangan perpustakaan digital. Dimensi-dimensi yang ada pada faktor ini menjadi bagian penting yang harus diperhatikan dalam pengembangan perpustakaan supaya hasilnya dapat memberikan pengetahuan pada pengguna khususnya pengguna potensial perpustakaan tentang pemanfaatan perpustakaan digital.

\section{c. Informational Aspect}

Faktor penting lainnya dalam pengembangan perpustakaan digital yang perlu diperhatikan adalah aspek informasional. Dimensi ini menyiratkan bahwa kualitas informasi yang disediakan pada perpustakaan digital harus mencakup berbagai macam format sumber informasi seperti jurnal elektronik, buku elektronik, database, dan sumber-sumber lainnya dalam bentuk elektronik/digital. Aspek ini juga mencakup publikasi informasi dengan konten-konten yang memiliki kualitas baik sehingga informasi yang disajikan pada masyarakat dapat memberikan manfaat serta nilai yang berguna.

d. Systemic Aspect

Pengembangan perpustakaan digital tidak lepas dari pemanfaatan sistem informasi, karena memang penggunaan jaringan dan sistem informasi menjadi bagian penting dalam membangun perpustakaan berbasis digital. Pengadaan perangkat keras dan sistem jaringan dengan kualifikasi yang tepat akan sangat mendukung terciptanya sebuah sistem perpustakaan digital yang berkualitas sehingga fungsi dan peran sistem tersebut dapat berjalan sesuatu dengan tujuan yang diharapkan perpustakaan dalam melakukan distribusi informasi bagi seluruh masyarakat khususnya yang termasuk dalam kategori pengguna potensial. Pengembangan perpustakaan digital harus memperhatikan bagaimana kualitas sistem yang menjadi sentral utama berjalannya perpustakaan digital, berikutnya fasilitas yang dipakai untuk menempatkan server perpustakaan digital harus representatif, sehingga keamanan dapat berjalan dengan baik serta bagaimana fitur perpustakaan digital akan dibuat sehingga tampilan (layout) serta menumenu yang disediakan dapat berfungsi dalam memenuhi kebutuhan masyarakat.

Kebijakan pengembangan perpustakaan digital harus ditelaah dengan baik supaya manfaat dari pengembangan tersebut dapat dirasakan oleh berbagai pihak. Kesalahkaprahan dalam pemahaman konsep perpustakaan digital harus mulai diluruskan. Pustakawan harus memahami dengan benar tujuan dari pengembangan perpustakaan digital, bukan serta merta mengikuti tren yang berkembang. Banyak aspek yang dapat dijadikan pertimbangan pengembangan perpustakaan digital sehingga penggunaan layanan dapat dinikmati oleh seluruh lapisan masyarakat.

Pengguna perpustakaan yang masuk dalam kategori pengguna potensial memang sangat sulit untuk diajak ke perpustakaan karena suatu hal yang membuat mereka tidak memiliki kesempatan untuk itu. Perpustakaan digital menjadi salah satu solusi untuk mendistribusikan informasi yang dimiliki perpustakaan pada seluruh komponen masyarakat. Oleh karena itu dalam merancang konsep perpustakaan digital yang baik maka pustakawan perlu mempertimbangkan berbagai masukan dan melakukan riset kebutuhan dan harapan pengguna supaya rancangan yang dibangun dapat berjalan efektif.

\section{KESIMPULAN}

Perpustakaan tidak hanya berkembang dalam penguatan teknologi informasi namun juga pengembangan kebijakan perpustakaan sebagai institusi yang lebih peduli dan memiliki kepekaan terhadap penggunanya, terutama pada kelompok masyarakat yang tidak memiliki 
kesempatan datang ke perpustakaan. Perpustakaan sebagai social institution wajib mengutamakan pelayanan yang adil dan merata. Perpustakaan memiliki pengguna dari masyarakat yang heterogen dengan karakteristik serta rutinitas individu yang berbeda-beda. Pengguna potensial perpustakaan termasuk bagian masyarakat pengguna perpustakaan yang mana kelompok ini memiliki perbedaan dalam hal keterbatasan kesempatan untuk dapat memanfaatkan perpustakaan. Kelompok masyarakat yang termasuk sebagai pengguna potensial perlu mendapatkan perhatian lebih dari pustakawan mengingat keterbatasan mereka dari segi waktu, kesempatan, dan fisik yang membuat mereka butuh perlakuan khusus dari perpustakaan.

Pengembangan perpustakaan digital menjadi salah satu solusi terhadap sebaran informasi perpustakaan yang dapat menjangkau seluruh kalangan termasuk kelompok pengguna potensial. Perpustakaan digital seharusnya dapat dikembangkan tepat guna dan tepat sasaran sehingga memberikan kebermanfaatan yang dirasakan oleh semua kelompok pengguna. Pengembangan perpustakaan digital dibangun dengan konsep kemudahan yang dirasakan oleh seluruh masyarakat seperti kemudahan akses, kemudahan pelayanan, kemudahan berliterasi dan sebagainya harus dimunculkan dalam perpustakaan digital. Perpustakaan harus memiliki respect and care terhadap masyarakat karena sebagai institusi sosial yang bergerak di bidang distribusi informasi dan pengetahuan, maka perpustakaan harus melayani masyarakat tanpa ada unsur ketidakberpihakan. Oleh karena itu pengembangan perpustakaan digital penting adanya mengingat perannya cukup sentral dalam distribusi informasi.

\section{REFERENCES}

Badan Pusat Statistik. (2018). Berita Resmi Statistik: Keadaan Ketenagakerjaan Indonesia Februari 2018. Retrieved December 6, 2019, from http://www.turc.or.id/wpcontent/uploads/2018/06/BPS_Berita-Resmi-Statsitik_Keadaan-KetenagakerjaanIndonesia-Februari-2018.pdf

Connaway, L. S. (2015). The Library in the Life of the User: Engaging with People Where They Live and Learn. Retrieved December 6, 2019, from OCLC Research website: https://www.oclc.org/content/dam/research/publications/2015/oclcresearch-library-inlife-of-user.pdf

Eriyanto. (2013). Analisis Isi: Pengantar Metodologi untuk Penelitian Ilmu Komunikasi dan Ilmu. Jakarta: Prenadamedia Group.

Firozjah, H. A., Dizaji, A. J., \& Hafezi, M. A. (2019). Usability Evaluation of Digital Libraries in Tehran Public Universities: Discovery Service for Perpustakaan Nasional Republik Indones. International Journal of Information Science \& Management, 17(2), 71-83. Retrieved from http://e-resources.perpusnas.go.id:2079/eds/detail/detail?vid=0\&sid=931eabb3-84394e55-b975-56b9d4dd13af\%40pdc-vsessmgr03\&bdata=JnNpdGU9ZWRzLWxpdmU\%3D\#AN=138266260\&db=lih

Hermawan, I. (2019). Metodologi Penelitian Pendidikan (Kualitatif, Kuantitatif dan Mixed Method). Kuningan: Hidayatul Quran.

Juhaidi, A., \& Syawqi, A. (2016). Perilaku Pencarian Informasi (Information Seeking Behaviour) Guru Besar IAIN Antasari Banjarmasin. Banjarmasin. Banjarmasin.

Nazir, M. (2013). Metode penelitian. Bogor: Ghalia Indonesia.

Rahimi, A., Soleymani, M. R., Hashemian, A., Hashemian, M. R., \& Daei, A. (2018). Evaluating Digital Libraries: a Systematised Review. Health Information \& Libraries Journal, 35(3), 180-191. https://doi.org/10.1111/hir.12231

Shea-Budgell, M. A., Kostaras, X., Myhill, K. P., \& Hagen, N. A. (2014). Information Needs and Sources of Information for Patients during Cancer Follow-up. Current Oncology, 21(4), 165173. https://doi.org/10.3747/co.21.1932

Singh, T., Sharma, A., \& Singh, N. (2015). Digital Library Acceptance Model and Its Social Construction: Conceptualization and Development. Journal of Web Librarianship, 9(4), 162181. https://doi.org/10.1080/19322909.2015.1099070 
Tedd, L. A., \& Large, A. (2005). Digital information sources. In L. A. Tedd \& J. A. Large (Eds.), Digital libraries: principles and practice in a global environment. München: Saur.

Yusup, M. P. (2009). Ilmu Informasi, Komunikasi dan Kepustakaan. Jakarta: Bumi Aksara.

Zed, M. (2008). Metode Penelitian Kepustakaan. Jakarta: Yayasan Pustaka Obor Indonesia. 